\title{
Blockchain in Indonesia University: A Design Viewboard of Digital Technology Education
}

Dudhat Amit ${ }^{1}$, Nuke Puji Lestari Santoso ${ }^{2}$, Henderi ${ }^{3}$, Sugeng Santoso ${ }^{4}$, Riri Setiawati ${ }^{5}$ Veer Narmad South Gujarat University ${ }^{1}$, University of Raharja ${ }^{2345}$

Email : amit000790@gmail.com¹, nuke@raharja.info², henderi@raharja.info $^{3}$, sugeng.santoso@raharia.info ${ }^{4}$, riri.setiawati@raharia.info ${ }^{5}$

Dudhat, A., Lestari Santoso, N. P., Henderi, Santoso, S., \& Setiawati, R. (2021). Blockchain in Indonesia University: A Design Viewboard of Digital Technology Education. Aptisi Transactions on Technopreneurship (ATT), 3(1), 68-80. DOI: https://doi.org/10.34306/att.v3i1.146

\section{Abstract}

The challenge that has often occurred in recent years is making access to education using a different learning process path. The presence of technology now provides solutions to problems that often occur such as communication, accessing information, and business or cooperation. The Blockchain Application Method is a technology that develops an evaluation model for itineraries in the learning process, both individually and in bulk. Currently the Edu blocs project has been designed and implemented, which combines elements of peer-to-peer learning and the teaching team. The aim of the Edu blocs project is to simplify the process of designing and implementing a system for recording activity results through blockchain technology. This ongoing project is in the process of evaluation. Conforming to some design elements as well as experimental implementation in the context of higher education enables us to further indicate the sustainability and relevance of the application of blockchain technology in education.

Keywords : University; Blockchain in Education; Learning; Digital Education.

\section{Introduction}

Information and communication technology has been used in learning education in schools and adult education. The advancement of information and communication technology at this time has changed the way people perceive and act in spending time working and overcoming all the problems that often occur, this makes society now very ambitious and dependent on technological advances $z$ [1]. In addition to basic knowledge, the Blockchain method is also able to implement so as to make changes to learning and dynamics in the teaching and learning process in schools. Transferring the mechanism found into the form of a game to increase the motivation for the teaching and learning process to meet the desired goals. According to Zichermann, gamification is a game mindset process and game mechanism to engage users and solve problems. The definition is more general. Blockchain is a technology which according to the distributed ledger is secure and offers opportunities for digital recording and information sharing over computer networks [2]. These types of information differ in context, but can include digital signatures, certificates, transaction assets, smart contracts, identities etc. Blockchain technology itself is a record in the form of a distributed database or a public / private ledger that has been used and shared by many users participating in the blockchain. Exploration 
of blockchain technology can solve problems that often occur and focus on learning applications, where it can be successful if it displays the features and advantages of blockchain technology [3]. Blockchain is a record (information base) that continues to grow, called blocks, which are connected and secured using cryptographic methods [4]. In each block contains the cryptographic hash of the previously connected block to the timestamp, as well as transaction data. Each block in this system is bound to each other and if there is data change in one block, it is mandatory to replace information in another block [5]. In the context of education, for example, information such as graduation certificates, test reports, academic achievement, performance metrics, academic profiles, career interests and so on can be mutually validated and transmitted. Information that is entered in the transparent ledger is communal, permanent, and accessible to the network [6]. In fact, the ledger that becomes the blockchain represents units of data that multiply over time with each update. With the presence of blockchain technology, it is hoped that it can increase the security, authenticity and validity of data from fake certificates, as well as if there is double data existence so that it can be minimized [7]. Defined protocols are used to decide how new entries are initiated, validated, recorded and distributed (Piscine, et al., 2016). Security and consistency are guaranteed in the Blockchain ledger through a consensus protocol that allows participants to run complex cryptologic algorithms to authenticate the integrity of the entire system. This technology can prevent changes or falsification of transactions so that users can trade directly with each other safely [8].

\section{General Background}

2.1 The influence of Blockchain in education

Perhaps the aspect that exists to maintain the level of user trust in the digital world is the confidentiality, integrity and truthfulness of the information obtained. As stated by (Tapscott, 2016), data confidentiality cannot be given to undesirable individuals, entities, or processes. Integrity is complete and accurate information, which cannot be changed in an illegal or unknown way [9]. Neither the recipient of the information nor the sender can manipulate the transactions of each party. Since the measurement of industrial society known as society, various digital circuits have developed to provide security and legality of every activity ranging from economic, political, social and cultural events in the digital world [10].

Today, we find ourselves with a new strategy that is recognized as a great tool that we hope will address this need for security. For some specialists, the possibilities that Blockchain offers in terms of information security, agility, and transparency in the digital world, will drastically increase the strength of not only the financial services industry, but also various other aspects of our society [11]. Technically, Blockchain is proving to be a new technology that disrupts event registration via distributed and replicated systems. This is especially true in the financial world, where cases like the Bank of England, as well as Visa, Santander, UBS, BNY Mellon, Deutsche Bank are just a few examples. Gap, the term can include several interpretations. Some describe how to record and store transactions of multiple cryptocurrencies, while others describe certain components of the Blockchain environment, including the rules governing system behavior [12]. The blockchain consists of a collection of applications, with special controls on cryptocurrency, and in particular BitCoin, the most recognized currency in the world. The success of Bitcoin is actually using a decentralized system based on tests that are registered by all users, guardians of their anonymity [13]. These attributes allow general interest to analyze the potential of Blockchain in areas such as digital identity, attention to marginalized groups, medical records, and of course, education [14]. Its 
emerging uses in education have attracted the attention of educators and researchers in the field, who are somewhat suspicious about the shortcomings and risks of these technologies in education, although they also attract some possibilities. In this regard, in 2017, Nicosia University became so high in the world that it authorized the diploma via Blockchain. But the most famous projects are from MIT and the British Open University. At MIT's Media Lab, Philipp Smith, director of del Learning Innovation, developed a certification proposal that is registered via Blockchain with the open standard, Blockcerts.

\section{Edublocks}

The Edublocs project is an initiative promoted by researchers from the Institute of Research in Education at the University of Barcelona. This initiative seeks to promote a training model that allows different student itineraries, but in which the four best performers, at different times and in different ways, guide travel plans [15]. Subject evaluation actors are: coaches, the subjects themselves, classmates and the automated system. In line with this, there is a need to offer students diverse and comprehensive scenarios, activities and resources to support their learning [16]. But problems arising from their encapsulation costs, the multitude of early standards, and the natural evolution of the Internet have reduced it to a symbolic presence. It should be added that, in most cases, this object is better called knowledge than learning because it is limited in feature content.

On the other hand, the Internet has flooded with a lot of space to find learning resources. Some are organized spaces, such as Khan Academy or Ted Ed. In other cases, they are resources framed in a training program such as OCW or multiple MOOCs. All of these do not have a complete training structure: objectives, levels of access, assessment mechanisms, which in most cases contain didactically organized content, and are far from changing initiatives that provide answers to knowledge [17]. a need that must be met in a digital society, in line with what Fullan \& Langworthy has to say about new knowledge and deeper learning. On the other hand, this whole approach focuses on the production of digital objects for online learning [18].

\section{Objective}

This part of the project seeks to implement via the Blockchain a management system for LO evaluation that supports student activity, and which compiles their personalized itinerary, different for each case. There is no previous documented experience since the use of Blockchain in Education in the three years that have passed since the University of Nicosia released its certificate or MediaLab started a block chart project, it focuses on academy accreditation certification [19]. The application of Blockchain to activity certification is hardly documented at the time of writing this line. Finally, the main objective of this project is to design and implement a system for recording activity results, together with management of the evaluation process via Blockchain.

\section{Proposal structure and implementation}

The itinerary is organized through what is initially called LO, and later, activities to avoid confusion. Each activity includes a design that includes: intended objectives, detailed descriptions of activities, expected products, evaluation procedures with the criteria to be applied, and other information needed to make decisions [20]. In addition, each activity offers an indication of previous requirements. And most importantly, each activity has a signature: the trainer designed it, and who will follow up on the students who carry out this activity. In our case, it is offered five types of activities organized into blocks. While some blocks are programmed at a specific date, others are developed over a long period of time [21].

4. The object of learning and evaluation

Since the early nineties, Wayne Hodgins understood learning objects as parts of 
learning that could be operated easily. Those that were accepted as solutions for training design in virtual environments, were then abandoned and redefined. And during this process, the evaluation of the learning achieved with the object has been one of the key elements of the problem. Student evaluation in both the formative and accreditation aspects is the competence of the teacher or tutor who is responsible for these subjects [22]. However, many authors have shown that this evaluation is concerned with objects.

This is the case the Guardia \& Sangrà analyzes. The reasons are several and several types of economy. Objects available in open mode on the network have assumed certain affordable costs, but if the object designer must also be responsible for the evaluation of students who, coming from other educational institutions or companies, use the object, they must be paid for their other work of a learning nature. namely evaluation in a training program is a complex process in which a coach-tutor exists to guide a student on his or her journey or to prove that he or she has achieved a certain goal or competency [23]. From this perspective, it becomes problematic if the evaluation is subject to criteria that have been made by a stranger, perhaps from another epistemological or didactic point of view. As a result, learning objects available on open networks rarely include learning evaluations. Even repositories that include evaluative items such as EdTed4, do so under the title Reflection, understanding that the evaluation is in the hands of the trainer or tutor in charge of the subject [24].

The solutions adopted in this project consisted of the distinction between two often confused traditional concepts of educational evaluation, namely evaluation of evaluative measurement results; and student evaluation processes, both formative and accredited [25]. In order to understand the following, we will use the terms assessment and evaluation appropriately from here on. In this perspective, the evaluation and assessment of learning achieved in an object, in accordance with the objectives being pursued, is an activity related to that object, which is proposed and must be carried out by the actor responsible for the object, namely the one concerned. concerned. who offers it in open mode on the Net. On the other hand, the evaluation of students' learning processes, their progress and, finally, the final achievement of the intended objectives or competency development are the appropriate tasks that are in charge of the training program that students participate in [26]. Such as instructor or teacher for the first function, and "facilitator" for the second function. It is possible to deny that an instructor is not required for an object of learning. This is false: the instructor can be either a machine or a person, but if the object includes some kind of assessment of learning it must be done by someone responsible for the learning [27]. Learning objects have not been designed for autonomous learning situations. It should be noted that LOs at Edublocs are offered on the Internet by experts or academics from educational institutions around the world and not by members of the same educational institutions as tutors. In this perspective, the first point follows a process similar to that currently on the Internet. Recent proposals using hirarc.

\section{Method}

The Edublocs project is in the full implementation phase during its first year. To analyze this initial stage 5 Implementation Evaluations have been carried out, to make improvements that can support the sustainability of the initiative. According to Lázaro \& Obregón, this evaluation aims to ensure that the implementation of an initiative is carried out well and in line with the ability to achieve the expected results [28]. In line with Sapag \& Sapaga, what we are looking for is to consider and assess each component of the project, using the same information generated in the resource and their own dynamics generated in the initial implementation of Edublocs. Therefore, the problem is whether the organization is properly regulated and 
regulated, namely whether it regulates the factors of production or functions that can regulate consistency and coherence to meet its original objectives. The exercise results have immediate importance in the process of transferring them if necessary, while providing us with information that is part of the general validation of the project [29].

The process of gathering and analyzing information

As we have mentioned, this article is the result of the Edublocs Implementation Evaluation that has been carried out to follow up the process of designing, developing and implementing the initiative. What it does following Padilla's line is to see project progress, problems as they arise, solutions found and the exact dimensions of unresolved problems. In this sense, Lázaro \& Obregón's proposal on Project Implementation Evaluation, suggests that the greatest possible input should be to analyze the various dimensions involved in project smoothness and work [30]. This, what is presented here is a joint analysis of the various evidence obtained from the use of various information strategies.

We refer to the minutes of the organization's meeting, email, and all supporting documentation of the agreement reached [31]. In our case, during the process, which began with the first meeting in February 2018 and continued with the start of the course in September, and ended at the end of the course in December, a detailed report was written explaining the problems detected and the decisions taken. This is done thanks to the individual fact that each of these examples is valid and transcribed [32]. Copies of the most significant letter exchanges made during the months between September and December are also kept, which makes it possible to follow certain decision-making processes. With the sources of information that have been obtained, the evidence grouping process has been carried out which encourages us to produce one content corpus. This, in line with Raigada and Scribano \& De Sena, has allowed us to provide an integral explanation of the evidence and therefore the questions that arise in the introduction to this article. The results have been organized into two main analytical dimensions.

\section{Result}

The results of this study provide an overview of the implementation evaluation carried out in the fourth month, namely the implementation of the Edubloc initiative. As we have mentioned, Results files have been grouped into two main dimensions, integrating data and information obtained in the process in each dimension. It is a process analysis i.e. the design evolution and the remaining problems.

4.1 Analysis of the evolutionary process

Development in this dimension consists of six sub-dimensions that describe the design process, associated costs, certification, and evaluation of the Edublocs project. The discussion section explains more about the process based on the Edublocs Gradebook which was created specifically for the Edublocs project. This allows permanent registration of class information. This Edublocs Gradebook is public and can be viewed in any browser on the default page or on pages for specific assignments. Almost anyone can add new records to the Edublocs Gradebook. 


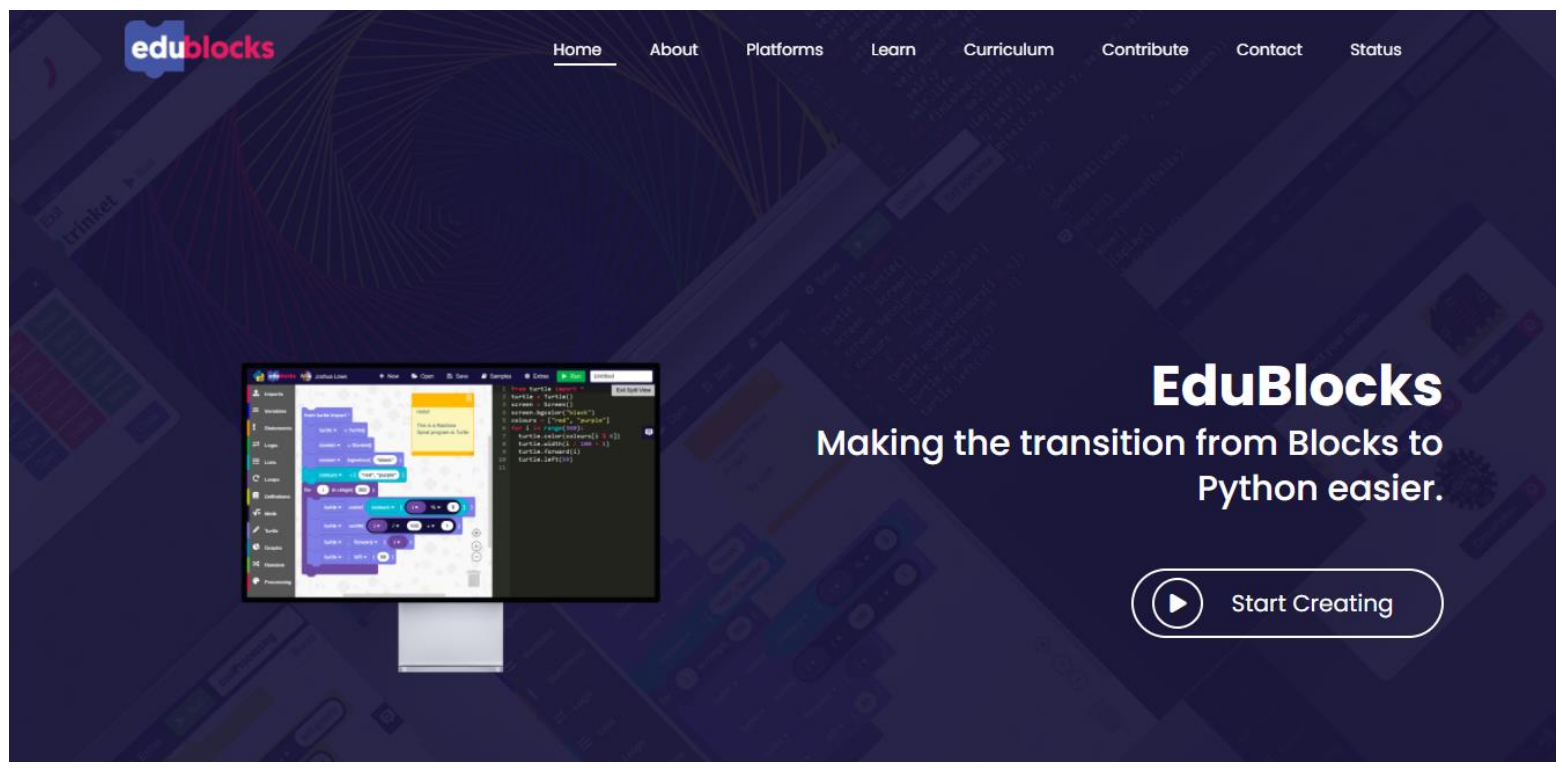

Figure 1. Edublocs Home display

On the right, the Rinkeby's private network widget, which supports transaction confirmation. However, it is an additional step for teachers who would be working in a typical management environment, namely opening a browser and transferring data. If we also take into account that, once the information is sent to Ethereum, the creation of blocks and notes is not done immediately, assuming a double step to simplify the trainer. With EGB, trainers can ignore the most cryptic aspects of the process, such as smart contract creation or block encryption [33]. This way, we can facilitate a smooth process. Indeed, consulting the results by students, a double step becomes necessary, because the information on the Blockchain is protected by a private password. Usually, in many Blockchain applications in the social sphere, the password belongs to the owner of the information, who records the information and who can disclose it.

In another project (Gräther \& OT. 2018), the solution also includes a double step: agents accessing the Blockchain are educational institutions that accredit and / or validate it. When a student wants to certify a learning unit, he or she goes to an educational institution that issues a certificate based on Blockchain records. And this is the strategy adopted here. This double step does not solve the problem of note-taking by the trainer and consultation by the tutor [34]. In the pilot version of the project, the problem does not occur because both use the same tools within the framework of a shared educational institution. The TEA application solves the problem, but does not solve it within the scalability intended in a future phase, where there is no common institutional umbrella.

Double step design

Part of the Edublocs project involved developing a team assessment management tool by teachers. The application is called TEA (Technology Enhanced Assessment). This app allows not only to measure LO but also for communication with students, reducing time and simplifying efforts. Therefore, a resource was introduced that supports this application to provide forms, only which leaves a record confirmation on the Net. Implementing Blockchain in experimental mode can cause malfunctions in applications. However, once deployed, its incorporation into the platform was immediate, requiring no additional assistance [35]. The double step is also used for students. Since students do not have a private record keeping password on the Blockchain, student records are identified through a private password. This password allows them to ask questions quickly and securely. They can also open the EGB directly, but in this case they have to manually extract the ones associated with them from the 
list of records on the Blockchain.

\subsection{Economic costs}

One of the most frequent criticisms made about Blockchain is its high cost. At that time, according to ethereum scores, each student had a fee of $€ 0.15$ or Rp. 2,592 and each note costs $€ 0.25$ or Rp. 4,320. Counting 160 students and 10 activities per student, this translates to $€ 440$ or Rp. $7,604,259$, with an average cost of $€ 2.65$ or Rp. 45,798 per student. This is an acceptable and scalable fee that is, a student covering 60 credits of an academic course with 10 subjects working under a similar system will be charged $€ 26.50$ or Rp. 457,983 . This represents between $1 \%$ and $2 \%$ of their enrollment. These fees are low but, as this is a pilot implementation, it was decided in September to work with a test network on Ethereum called Ropsten11. Then, during implementation, we worked with another private network called Rinkeby12.

To understand this technical change, we must remember that Blockchain and Ethereum are cutting-edge technologies and are constantly changing. The test network objected to the problems arising from this change. This is what happened with the Ropsten network, because problems were detected when they started introducing the first mass recording, according to LOs 11, 12 and 13. The company that developed EGB suggested the best solution was to change the network. Each record contains an identifier of who entered the information, the student involved, the activity evaluated, and the five marks assigned for weighted complexity, effort, relevance in subject, grade obtained, and grade assigned weight.

\begin{tabular}{|l|l|}
\hline Recorder & $\begin{array}{l}\text { is a string consisting of } 42 \text { characters with format } \\
\text { N9HKvBotq78LueAwuqRyxus1rKJrWdZD1r3NvJrc2r4= }\end{array}$ \\
\hline Student & $\begin{array}{l}\text { Character string; there is no practical limit, but the cost of one: the } \\
\text { longer, the higher the registration fee }\end{array}$ \\
\hline Activity & 0 a 4453920374 \\
\hline Complexity & $0-10$ \\
\hline Effort & $0-10$ \\
\hline Weight & $0-10$ \\
\hline Points & $0-10$ \\
\hline Weighted Points & $0-10$ \\
\hline
\end{tabular}


This limit is entered into the EGB. This nuance is interesting because in reality it can be between 0 and 24.5. Simple changes to the new value usage interface.

\subsection{LO assessment to student evaluation}

Tutors can at any time consult with their group students and check their progress on the proposed itinerary. In addition, it allows them to make changes to their travel plans and have a vision of how they are progressing. This need not be the case and both can use evaluation management systems and other LMS. The point of unification is the LO rating record on the Blockchain. For example, although tutors can access the scores recorded by different trainers for their students, and the overall scores to be earned each time in the process, these are not automatically identified by subject evaluation [36]. Tutors can use other additional indicators to create their own evaluation reports. The most paradigmatic case is the final class case.

\subsection{Learning certification}

For this purpose, in the student consultation page which made it possible to compare the results with their peers and their perceptions of the way they worked, it was decided to add an option to get a work certificate in one of the activities [37]. In records gleaned from studentmade use of direct consultations to the Blockchain, we found 1205 queries for a total of 130 subjects. Of these, only 30 fit this certificate. There were 66 consultations on matters related to self-regulation of learning, a relatively insignificant number [38].

1. Problem

Cultural and communicated via fast and direct channels. Therefore, the analysis tries to find out what elements will not work in the scalability of the system, although in a pilot study this might be something that would be easy to solve. In this sense, we found four aspects worth considering, and which we will describe now.

\section{Process}

When multiple notes are introduced it is possible to use management techniques that make the wait even more bearable. However, in general, this is a process that teachers find slow, getting used to the fact that introducing grades is something quite fast. In this case, downloading all the recordings that fit at least 140 students can take more than 10 minutes. Given that the system acts as an intermediary in two steps for student consultation as previously described, the solution chosen for now is that the downloading of all notes is done periodically, rather than when students ask questions [39]. This is a problem that has not appeared until now in the literature on Blockchain applications. In the case of itineraries, this may not be a fundamental requirement, but it is still an emerging problem.

3. Information recovery

We have previously referred to this issue. In the case of students, this is not the case. They cannot access private passwords; Therefore, their certificates are always issued by educational institutions. At Edublocs, coaches and tutors have access to passwords. But this may not be true in their scaled system in which educators from different educational institutions participate with one function or another [40]. Obviously, the key to encrypting should be in the hands of the trainer, as they were the ones who introduced the notes. It is true that there is a variable that identifies the trainer who introduced the record, but it allows the imitation of one trainer with another [41]. The use of identifiers alone is not sufficient, as a review of a series of records that is not very large is sufficient to quickly identify which passwords are compatible with other trainers.

4. Information security

One of the most attractive options for students of this educational proposal, is the 
possibility to be able to prove in successive courses or even to future employers, a particular learning acquired and validated. But in the case of other teachers, the situation is more interesting [42]. A conscious teacher may try to make sure his student has these skills.

\section{Economic costs}

We have analyzed the cost of the project. We've seen the project cost this year is $€ 424$ or Rp. $7,327,740$. This is a theoretical cost of ending up working with the private Rinkeby 14 network. But let's scale the project one more time. Even though costs are lowered, they don't stop being costs. The most important problem arises in the distribution of costs [43]. The Edublocs project is based on the fact that a teacher or tutor from a group, acting as a trainer in the LO, judges students against other teachers. It is clear that it is possible to limit the number of students admitted [44]. Attending 300 students in the LO was not problematic from the time where, in another LO, he had benefited from work being done by another trainer. Job distribution is not a problem in this pilot study. The course was finally conducted by 119 students, which counted with an offer of $14 \mathrm{LO}$. The distribution of students can be seen in table 2 .

\begin{tabular}{|l|l|}
\hline Object of Learning & Student Learning Object \\
\hline 11 & 40 \\
\hline 12 & 83 \\
\hline 13 & 19 \\
\hline 21 & 27 \\
\hline 22 & 50 \\
\hline 23 & 46 \\
\hline
\end{tabular}




\begin{tabular}{|l|l|}
\hline 31 & 102 \\
\hline 32 & 64 \\
\hline 33 & 104 \\
\hline 41 & 114 \\
\hline 51 & 115 \\
\hline
\end{tabular}

Table 2. Number of students per Learning Object

The three trainers who carried out the evaluation task had a relatively homogeneous distribution in each LO, as shown in table 3.

\begin{tabular}{|l|l|l|}
\hline Coach & OA Evaluation & $\mathrm{n}$ \\
\hline Form 1 & $21,22,25,26,31$ & 194 \\
\hline Form 2 & $12,23,24,32$ & 259 \\
\hline Form 3 & $11,13,41$ & 173 \\
\hline
\end{tabular}

Table 3. Homogeneous Distribution Table

Of the 14 LOs, there were two whose evaluations were carried out differently. For LO 33 , this was evaluated by the students themselves, so the role of the trainer was limited to coordination work. In the case of LO 51, the evaluation is distributed among the three tutors, because it is a final assignment.

\begin{tabular}{|l|l|}
\hline Form 1 & $€ 85.08$ \\
\hline Form 2 & $€ 74.08$ \\
\hline Form 3 & $€ 53.73$ \\
\hline
\end{tabular}

Table 4. Payment finance 
With regard to this data, the following question is asked: is the trainer ready to accept this payment? Will a way to finance this expenditure be found, apart from a special grant associated with the project? It is true that there are not many, but we propose a system that should work in a loose and global network of educators. The challenge, therefore, is to think about how these costs can be covered.

\section{Conclusion}

The evaluation carried out in the implementation of the Edublocs project allows us to identify a set of important elements which will of course be very useful for seeking sustainability. In its design with process analysis and evolution, we assume that, in general, the system works [45]. The interruption in the process ended and was finally carried out. However, from the experience of this pilot and the possibilities required for daily recovery and recovery processes, we believe that without Blockchain, it would be impossible to design, implement and manage learning proposals in a global environment as planned. The costs associated with design are not very high, but it is difficult to find ways to be accepted by the educators involved a new phase started in February 2019 involving actors and design changes that allow scalability. Regarding the question that arises in the introduction that guides this research: what are the limitations of using Blockchain in evaluating [46]. The Edublocs project, allowing students to create their own study schedules, has encouraged students to realize the potential contribution that the application of LO can make to their learning. With regard to the use of Blockchain in projects, it is possible to pay attention to its potential, not only for the implementation of this particular initiative, but also for personalized learning itineraries in a global environment [47]. With students, teacher-tutors, and LO trainers from various organizations and countries, Blockchain offers a systems system that guarantees the various actors that make up the learning process, as well as the skills that are assimilated. In parallel, information about the learning process is safe, legitimized and validated by the actors, and can be accessed globally, safely and confidentially. Thus, the faculty can become a special instructor in courses that are presented with almost the same subjects according to the specific needs of each university.

\section{Acknowledgement}

The author would like to express his deepest gratitude to University of Raharja for providing a welcoming forum for guidance in the completion of this journal.

\section{Reference}

[1] A. Asmawi, S. Syafei, and M. Yamin, "Pendidikan Berbasis Teknologi Informasi dan Komunikasi," 2019.

[2] Q. Aini, U. Rahardja, M. R. Tangkaw, N. P. L. Santoso, and A. Khoirunisa, "Embedding a Blockchain Technology Pattern Into the QR Code for an Authentication Certificate," J. Online Inform., vol. 5, no. 2, 2020.

[3] M. Takdir, "KEPOMATH GO 'Penerapan Konsep Gamifikasi Dalam Pembelajaran Matematika Dalam Meningkatkan Motivasi Belajar Matematika Siswa,"' Indones. J. Educ. Stud., vol. 20, no. 1, 2017.

[4] E. Guustaaf, U. Rahardja, Q. Aini, H. W. Maharani, and N. A. Santoso, "Blockchainbased Education Project," Aptisi Trans. Manag., vol. 5, no. 1, pp. 46-61, 2021.

[5] B. S. Riza, "Blockchain Dalam Pendidikan: Lapisan Logis di Bawahnya," ADI Bisnis Digit. Interdisiplin J., vol. 1, no. 1, pp. 41-47, 2020.

[6] F. P. Oganda, U. Rahardja, Q. Aini, M. Hardini, and A. S. Bist, "BLOCKCHAIN: VISUALIZATION OF THE BITCOIN FORMULA," PalArch's J. Archaeol. Egypt/Egyptology, vol. 17, no. 6, pp. 308-321, 2020.

[7] A. U. Hamdani, "Penjualan Online Berbasis E-Commerce Pada Toko Adhizzshop Dengan Menggunakan Woocommerce," IDEALIS Indones. J. Inf. Syst., vol. 3, no. 1, pp. 26-33, 2020. 
[8] S. Sudaryono, N. P. Lestari, and K. Gunawan, "PERANCANGAN VIRTUAL ASSISTANT ENTREPRENEURSHIP MENGGUNAKAN METODE SCRUM," J. Innov. Futur. Technol., vol. 2, no. 2, pp. 66-77, 2020.

[9] P. A. Sunarya, U. Rahardja, L. Sunarya, and M. Hardini, "The Role Of Blockchain As A Security Support For Student Profiles In Technology Education Systems," InfoTekJar J. Nas. Inform. dan Teknol. Jar., vol. 4, no. 2, pp. 13-17, 2020.

[10] U. Rahardja, S. Kosasi, E. P. Harahap, and Q. Aini, "Authenticity of a Diploma Using the Blockchain Approach," Int. J., vol. 9, no. 1.2, 2020.

[11] U. Rahardja, E. P. Harahap, and D. D. Christianto, "PENGARUH TEKNOLOGI BLOCKCHAIN TERHADAP TINGKAT KEASLIAN IJAZAH," Technomedia J., vol. 4, no. 2, pp. 211-222, 2020.

[12] M. Herlina, U. S. Sa'ud, D. Disman, W. Sopandi, and N. P. L. Santoso, "Pengembangan dan Kesiapterapan Jiwa Kewirausahaan pada Siswa Sekolah Dasar," J. Pemikir. dan Pengemb. Sekol. Dasar, vol. 8, no. 2, pp. 96-106, 2020.

[13] U. Rahardja, T. Nurhaeni, A. Khoirunisa, and R. D. I'zzaty, "LTAI BERBASIS TEKNOLOGI BLOCKCHAIN UNTUK MENINGKATKAN ALEXA RANK," in SENSITIf: Seminar Nasional Sistem Informasi dan Teknologi Informasi, 2019, pp. 373-380.

[14] G. Maulani, A. H. Arribathi, U. Rahardja, M. Hardini, and N. P. L. Santoso, "Information Media In Video Tourism, Art and Historic Building In Tangerang City-Indonesia," Solid State Technol., pp. 4550-4566, 2020.

[15] E. P. Fedorova and E. I. Skobleva, "Application of Blockchain Technology in Higher Education,” Eur. J. Contemp. Educ., vol. 9, no. 3, pp. 552-571, 2020.

[16] A. Adiyanto and R. Febrianto, "Authentication Of Transaction Process In E-marketplace Based On Blockchain?? technology," Aptisi Trans. Technopreneursh., vol. 2, no. 1, pp. 68-74, 2020.

[17] G. N. B. Safrizal and G. N. Budiadyana, "Analysis Application Design Career Development Center in The STMIK Insan Pembangunan and (Case Study: Information Study Program)," IAIC Trans. Sustain. Digit. Innov., vol. 1, no. 1, pp. 66-77, 2019.

[18] Q. Aini, U. Rahardja, N. P. L. Santoso, and A. Oktariyani, "Aplikasi Berbasis Blockchain dalam Dunia Pendidikan dengan Metode Systematics Review," CESS (Journal Comput. Eng. Syst. Sci., vol. 6, no. 1, pp. 58-66.

[19] P. A. Sunarya, Q. Aini, A. S. Bein, and P. Nursaputri, "The Implementation Of Viewboard Of The Head Of Department As A Media For Student Information Is Worth Doing Final Research," ITSDI J. Ed., vol. 1, no. 1, p. 18, 2019.

[20] G. Antarnusa and S. Ristantiya, "Kuliah Kerja Mahasiswa Guna Meningkatkan Kualitas Sumber Daya Manusia Pada Desa Sukabares Kecamatan Ciomas," ADI Pengabdi. Kpd. Masy., vol. 1, no. 1, pp. 37-50, 2020.

[21] Q. Aini, M. Budiarto, P. O. H. Putra, and N. P. L. Santoso, "Gamification-based The Kampus Merdeka Learning in 4.0 era," IJCCS (Indonesian J. Comput. Cybern. Syst., vol. 15, no. 1, pp. 31-42.

[22] T. Alam, "Cloud Computing and its role in the Information Technology," Tanweer Alam.(2020). Cloud Comput. its role Inf. Technol. IAIC Trans. Sustain. Digit. Innov., vol. 1, no. 2, pp. 108-115, 2020.

[23] R. S. Pandey, V. Srivastava, and L. B. Yadav, "Research trends and solutions for secure traffic management of SDN," Aptikom J. Comput. Sci. Inf. Technol., vol. 2, no. 3, pp. 97105, 2017.

[24] F. Agustin, Q. Aini, A. Khoirunisa, and E. A. Nabila, "Utilization of Blockchain Technology for Management E-Certificate Open Journal System," Aptisi Trans. Manag., vol. 4, no. 2, pp. 133-138, 2020.

[25] Y. Ramesh and K. K. Reddi, "RK algorithm: stochastic parallel methodology for symmetric key cryptography," Aptikom J. Comput. Sci. Inf. Technol., vol. 2, no. 3, pp. 137-144, 2017.

[26] U. Rahardja, Q. Aini, and A. Khoirunisa, "Effect of iDu (iLearning Education) on Lecturer Performance in the Lecture Process," Aptisi Trans. Manag., vol. 2, no. 2, pp. 140-148, 2018.

[27] M. T. Hammi, B. Hammi, P. Bellot, and A. Serhrouchni, "Bubbles of Trust: A decentralized blockchain-based authentication system for loT," Comput. Secur., vol. 78, pp. 126-142, 2018. 
[28] S. Sudaryono, L. Sunarya, and G. Maulani, "Facility for Customizing Transaction Forms on Master Data Using an Online Accounting System Web For Work Efficiency Company," Aptisi Trans. Manag., vol. 1, no. 1, pp. 17-23, 2017.

[29] A. H. Arribathi, M. Maimunah, and D. Nurfitriani, "Implementation System of Business Intelligence System In The Company," Aptisi Trans. Agric., vol. 1, no. 1, pp. 21-30, 2017.

[30] S. Sudaryono, Q. Aini, N. Lutfiani, F. Hanafi, and U. Rahardja, "Application of Blockchain Technology for iLearning Student Assessment," IJCCS (Indonesian J. Comput. Cybern. Syst., vol. 14, no. 2, pp. 209-218.

[31] S. Kosasi, "Karakteristik Blockchain Teknologi Dalam Pengembangan Edukasi," ADI Bisnis Digit. Interdisiplin J., vol. 1, no. 1, pp. 87-94, 2020.

[32] M. Kamil, A. S. Bist, U. Rahardja, N. P. L. Santoso, and M. Iqbal, "Covid-19: Implementation e-voting Blockchain Concept," Int. J. Artif. Intell. Res., vol. 5, no. 1, 2021.

[33] U. Rahardja, N. Lutfiani, and A. Yolandari, "Penerapan Viewboard Informatif Pada Asosiasi Perguruan Tinggi Swasta Indonesia Dalam Era Industri 4.0," Technomedia J., vol. 3, no. 2, pp. 224-234, 2019.

[34] U. Rahardja, Q. Aini, and F. Faradilla, "Implementasi Viewboard Berbasis Interaktif Javascript Charts Pada Sistem Penilaian Perkuliahan," J. IIm. Teknol. Inf. Asia, vol. 12, no. 2, pp. 91-102, 2018.

[35] P. O. A. Sunarya and N. Lutfiani, "Analisis Sistem Sertifikasi Profesi Untuk Pengembangan Kompetensi Mahasiswa," ADI Bisnis Digit. Interdisiplin J., vol. 1, no. 1, pp. 70-77, 2020.

[36] U. Rahardja, Q. Aini, and A. Khoirunisa, "The Effect of Rinfogroups as a Discussion Media in Student Learning Motivation," Aptisi Trans. Manag., vol. 2, no. 1, pp. 79-88, 2018.

[37] A. Argani and W. Taraka, "Pemanfaatan Teknologi Blockchain Untuk Mengoptimalkan Keamanan Sertifikat Pada Perguruan Tinggi," ADI Bisnis Digit. Interdisiplin J., vol. 1, no. 1, pp. 10-21, 2020.

[38] U. Rahardja, E. Febriyanto, and M. A. Aldiya, "Penerapan Central Event Information Untuk Mencetak Sertifikat dan Verifikasi Dengan QR Code Menggunakan Global Extreme Programming," J. Inform. Upgris, vol. 4, no. 2, 2018.

[39] U. Rahardja, E. P. Harahap, and G. Fresandy, "Penerapan Sistem Autentikasi Sertifikat Sebagai Pengambil Keputusan Validasi Sertifikat Pada Perguruan Tinggi," Technomedia J., vol. 2, no. 1, pp. 17-25, 2017.

[40] Q. Aini, U. Rahardja, A. Moeins, and D. M. Apriani, "Penerapan Gamifikasi pada Sistem Informasi Penilaian Ujian Mahasiswa Untuk Meningkatkan Kinerja Dosen," J. Inform. Upgris, vol. 4, no. 1, 2018.

[41] U. Rahardja, A. Moein, and N. Lutfiani, "Leadership, competency, working motivation and performance of high private education lecturer with institution accreditation B: Area kopertis IV Banten province," Man India, vol. 97, no. 24, pp. 179-192, 2018.

[42] Q. Aini, U. Rahardja, H. Madiistriyatno, and Y. D. M. Setiaji, "Pengamanan Pengelolaan Hak Akses Web Berbasis Yii Framework," Syntax J. Inform., vol. 7, no. 1, pp. 52-63, 2018.

[43] U. Rahardja, Q. Aini, and M. Hardini, "Penerapan Software Akuntansi Online Sebagai Penunjang Pencatatan Laporan Keuangan," Sisfotenika, vol. 8, no. 2, pp. 176-187, 2018.

[44] U. Rahardja, Q. Aini, and A. Khoirunisa, "Monitoring Kinerja User Akuntan Menggunakan Dashboard Pada Web Based Accounting Online di Perguruan Tinggi," Sains dan Teknol. Inf., vol. 4, no. 2, pp. 58-62, 2018.

[45] Q. Aini, B. S. Riza, N. P. L. Santoso, A. Faturahman, and U. Rahardja, "Digitalization of Smart Student Assessment Quality in Era 4.0," Int. J., vol. 9, no. 1.2, 2020.

[46] B. S. Riza, M. Y. Mashor, and E. V. Haryanto, "The Application of RSA and LSB in Securing Message on Imagery," ADI J. Recent Innov., vol. 1, no. 1, pp. 20-32, 2019.

[47] S. Sutirna, "Total Quality Management Through Lecturer Assessment With Students to Improve Graduate Quality," ADI J. Recent Innov., vol. 2, no. 1, pp. 51-65, 2020. 